\title{
Editorial \\ COVID-19 dan Tumit Achilles Iman Kristen
}

\author{
David Alinurdin \\ Ketua Penyunting \\ david.alinurdin@seabs.ac.id
}

Awal tahun 2020 ditandai dengan satu peristiwa yang mengejutkan seluruh dunia. Virus Corona baru yang merebak di Wuhan, China sejak akhir 2019, secara masif mulai menyebar ke berbagai negara di seluruh penjuru dunia, menjadi sebuah pandemi yang disebut COVID-19 (Corona Virus Disease 2019). Umat manusia di seluruh dunia dihadapkan pada satu kondisi yang mengejutkan dan meluluhlantakkan berbagai sendi kehidupan. Bukan hanya kekuatiran akan penderitaan fisik yang diakibatkan oleh COVID-19, namun juga seluruh aspek kehidupan politik, ekonomi, sosial, hingga religiositas dan spiritualitas manusia menjadi terganggu.

Masalah penderitaan dapat diumpamakan seperti "tumit Achilles" atau titik lemah dari iman Kristen. Manusia sudah bergumul selama berabad-abad untuk menjawab pertanyaan bagaimana mungkin Allah yang baik dan penuh kasih mengizinkan kejahatan dan penderitaan sedemikian merajalela di dalam dunia ciptaan-Nya, dan hingga hari ini masih terus bergumul dengan pertanyaan yang sama. Terlebih lagi saat ini ketika melihat kondisi dunia yang porak-poranda akibat pandemi COVID-19, di antara kita mungkin ada yang bertanya apakah Allah sungguh ada? Apakah Dia sungguh Allah yang berdaulat dan mahakuasa yang masih terus bertindak di dalam dunia ini ataukah Dia sudah lepas tangan dan membiarkannya berjalan sendiri? Apakah Dia sungguh Allah yang baik dan peduli terhadap penderitaan yang terjadi di dalam dunia? Jika Dia adalah Allah yang baik, mengapa Dia menciptakan dunia ini dengan virus patogen yang menyebabkan berbagai penyakit mematikan? Lalu, bagaimanakah kita sebagai gereja, umat Allah yang telah diselamatkan dan diutus kembali ke tengah dunia ini, dapat berkarya menyatakan kehadiran-Nya yang mahakuasa dan mahabaik itu secara konkret kepada dunia yang sedang bergumul saat ini? Beberapa pertanyaan krusial di atas akan didiskusikan dan dijawab dalam editorial ini.

\section{APAKAH ALLAH ITU ADA?}

Adanya kejahatan dan penderitaan di dalam dunia seringkali dipakai sebagai argumen untuk menentang keberadaan Allah. J.L. Mackie, seorang filsuf ateis terkemuka melontarkan pertanyaan kepada mereka yang memercayai keberadaan Allah yang mahabaik dan mahakuasa, dengan menggunakan tiga proposisi berikut ini: (1) Allah itu mahakuasa; (2) Allah itu mahabaik; dan (3) Kejahatan itu ada. ${ }^{1}$

Mackie menyatakan bahwa ada kontradiksi antara proposisi pertama dan kedua dengan proposisi ketiga. Menurut Mackie, jika Allah

${ }^{1}$ J.L. Mackie, "Evil and Omnipotence," Mind 64 no. 254 (April 1955): 200, https://doi.org/10.1093/mind/LXIV. 254.200. 
yang dipercayai oleh kaum teisme adalah Allah yang mahakuasa dan mahabaik maka kejahatan itu tentu tidak ada, karena Allah yang mahabaik tentu ingin melenyapkan kejahatan dan dengan kemahakuasaan-Nya tentu Ia sanggup mewujudkan hal tersebut. ${ }^{2}$ Karena itu, jika kejahatan dan penderitaan ada di dalam dunia maka tentu Allah tidak ada.

Apakah benar argumen keberadaan kejahatan meniadakan keberadaan Allah? Malah justru sebaliknya. William L. Craig berargumen bahwa adanya nilai-nilai moral yang objektif di dalam diri manusia dan di tengah kehidupan masyarakat, seperti baik dan jahat, benar dan salah, mengindikasikan adanya Sang Sumber nilai yang sejati, yaitu Allah sendiri. ${ }^{3}$ Jika manusia bisa menilai apa yang terjadi di dalam dunia saat ini adalah sesuatu yang salah atau buruk, maka konsep nilai itu bersumber dari Pribadi Allah sendiri yang adalah baik. Lebih lanjut, kalau Allah itu ada, apakah Dia adalah Allah yang berdaulat dan mahakuasa yang masih terus bertindak di dalam dunia ini?

\section{APAKAH ALLAH MASIH BERTINDAK?}

Adanya kejahatan dan penderitaan dalam dunia memunculkan pertanyaan kedua: apakah Allah masih bertindak? Apakah Dia Allah kaum Deisme yang menciptakan dunia ini dan kemudian membiarkannya begitu saja untuk berjalan sendiri? Ataukah Dia Allah yang masih terus menyertai umat-Nya dan terus bekerja di dalam dunia ini? C.S. Lewis berkata bahwa penderitaan justru adalah semacam pengeras suara dari Allah, yaitu teriakan-Nya yang sangat keras untuk membangunkan dunia yang tuli. ${ }^{4}$ Pandemi COVID-19 ini dapat dikatakan sebagai se-

${ }^{2}$ Ibid., 201.

${ }^{3}$ William L. Craig, Five Arguments for God: The New Atheism and the Case for the Existence of God (London: Christian Evidence Society, 2016), 20-23.

${ }^{4}$ C.S. Lewis, The Problem of Pain (1940; repr., New York: HarperCollins, 2009), 91, Adobe PDF ebook. buah peringatan yang kuat kepada kita, umat manusia, yang telah lalai dan abai di dalam mengindahkan Allah Sang Pencipta dan kehendak-Nya dalam hidup kita. Dengan kata lain, di dalam dan melalui penderitaan, Allah tidak meninggalkan kita melainkan sedang berbicara kepada kita, dan bahkan sedang hadir dan bertindak di dalam kehidupan kita.

Dalam edisi ini, tulisan dari Martus A. Maleachi dan Hendra Yohanes yang berjudul "Kehadiran Tuhan di Tengah Umat-Nya: Dari Penciptaan ke Penciptaan yang Baru" menjabarkan bahwa Alkitab justru memperlihatkan sebuah kesinambungan kehadiran Allah yang senantiasa berdiam di tengahtengah umat-Nya, mulai dari taman di Eden, Kemah Suci, Bait Suci, Yesus Kristus, Roh Kudus yang diam di dalam umat percaya hingga langit dan bumi yang baru kelak. ${ }^{5}$ Motif biblikal ini memperlihatkan bahwa Allah tidak pernah meninggalkan umat-Nya, dan oleh sebab itu, umat-Nya pun memiliki tanggung jawab untuk hidup dalam kekudusan dan kebenaran, serta terus menyatakan kebaikan dan kemuliaan Allah di tengah dunia ini.

Allah yang senantiasa hadir di tengah umatNya ini juga adalah Allah yang bertindak secara aktif di dalam dunia ciptaan-Nya. Meskipun naturalisme berusaha menyingkirkan Allah dari dalam dunia ini, namun teologi tidak bertentangan dengan sains di dalam memperlihatkan bagaimana Allah yang transenden dapat bertindak secara imanen di dalam dunia ini untuk mengarahkan seluruh ciptaan kepada tujuan teleologis dan eskatologis yang dikehendaki-Nya. Tulisan dalam edisi ini yang berjudul "Allah versus Setan Laplace: Sebuah Usulan Konsep Tin-

${ }^{5}$ Martus A. Maleachi dan Hendra Yohanes, "Kehadiran Tuhan Di Tengah Umat-Nya: Dari Penciptaan Ke Penciptaan Yang Baru," Veritas: Jurnal Teologi dan Pelayanan 19, no. 1 (2020): 11-24, https://doi.org/10.36421/ veritas.v19i1.361. 
dakan Ilahi Khusus yang Trinitarian, Kovenantal dan Saintifik" akan memperlihatkan hal ini. ${ }^{6}$

Realitas konkret dari kehadiran dan tindakan Allah di dalam dunia adalah inkarnasi Yesus Kristus, Allah yang mengejawantah menjadi manusia, tinggal di antara manusia dan dapat turut merasakan sepenuhnya kehidupan yang manusia jalani. Banyak orang yang meragukan keilahian Yesus Kristus atau pun mengatakan doktrin inkarnasi ortodoks adalah mitos belaka, seperti yang diutarakan John Hick. Tulisan Fitri Yuliani yang berjudul "Menjawab Tuduhan Inkoherensi dari John Hick terhadap Konsep Dwinatur dalam Doktrin Inkarnasi Ortodoks" akan memaparkan argumentasi secara logis mengenai koherensi dari konsep dwinatur Yesus Kristus. ${ }^{7}$ Kehadiran dan tindakan Allah di dalam Yesus Kristus sekaligus juga menunjukkan bukti konkret kasih Allah kepada manusia berdosa, seperti yang dikatakan rasul Yohanes dalam Injilnya (Yoh. 3:16) dan rasul Paulus dalam suratnya kepada jemaat di Roma (Rm. 5:8).

Jadi, dari ketiga tulisan ini, keyakinan iman kita kepada Allah dikokohkan kembali. Allah yang transenden, mahakuasa dan mahabaik itu tidak abai melihat penderitaan umat manusia. Dia bertindak secara imanen dan konkret di dalam Yesus Kristus untuk mendemonstrasikan Allah yang solider dengan manusia, bahkan merengkuh penderitaan manusia di dalam penderitaan dan kematian-Nya sendiri demi menyelamatkan mereka. Di dalam Kristus, Allah bukan hanya menunjukkan kemahabaikan-Nya kepada

${ }^{6}$ David Alinurdin, "Allah versus Setan Laplace: Sebuah Usulan Konsep Tindakan Ilahi Khusus yang Trinitarian, Kovenantal dan Saintifik," Veritas: Jurnal Teologi dan Pelayanan 19, no. 1 (2020): 25-49, https://doi.org/10.36421/ veritas.v19i1.340.

${ }^{7}$ Fitri Yuliana, "Menjawab Tuduhan Inkoherensi dari John Hick terhadap Konsep Dwinatur dalam Doktrin Inkarnasi Ortodoks," Veritas: Jurnal Teologi dan Pelayanan 19, no. 1 (2020): 51-68, https://doi.org/10.36421/ veritas.v19i1.344. manusia tetapi juga kemahakuasaan-Nya dan kemenangan-Nya atas kejahatan, seperti yang dikatakan oleh D.A. Carson, "God is sovereign, yet in the person of his Son, he submits to evil to overturn evil." 8 Namun demikian, kita jadi bertanya-tanya, jika memang Dia adalah Allah yang mahabaik dan mahakuasa, mengapakah Dia menciptakan dunia ini dengan kejahatan dan penderitaan yang ada di dalamnya, termasuk virus patogen yang menyebabkan penyakit mematikan?

\section{MENGAPA ALLAH MENCIPTAKAN DUNIA YANG ADA KEJAHATAN DAN PENDERITAAN?}

Jika Allah mahabaik, mengapa Dia menciptakan dunia yang, menurut pandangan kita, tidak baik? Bukankah Allah yang mahakuasa sanggup menciptakan dunia tanpa adanya kejahatan dan penderitaan? Pembelaan terhadap kemahaadilan dan kemahabaikan Allah di tengah realita adanya kejahatan serta penderitaan yang sedang terjadi di dalam dunia disebut theodicy. ${ }^{9}$ Salah satu teodisi yang diakui dan digunakan secara luas adalah pembelaan kehendak bebas yang disampaikan oleh Alvin Plantinga. ${ }^{10}$ Sama seperti Allah tidak mungkin bisa membuat persegi yang berbentuk lingkaran, maka Dia juga tidak mungkin bisa membuat sebuah dunia dengan manusia yang memiliki kapasitas moral untuk memilih yang baik dan benar dengan kehendaknya sendiri secara bebas tanpa memberi kemungkinan untuk memilih yang buruk atau salah.

${ }^{8}$ D.A. Carson, "Biblical-Theological Pillars Needed To Support Faithful Christian Reflection On Suffering And Evil," Trinity Journal 38NS (2017): 73.

${ }^{9}$ Theodicy berasal dari bahasa Yunani theos yang artinya "Allah" dan dike yang artinya "keadilan." Penjelasan lebih rinci mengenai hal ini dapat dilihat dalam Esther Gunawan, "Meneropong Makna Penderitaan Manusia Menurut Konsep Teodise C.S. Lewis," Veritas: Jurnal Teologi dan Pelayanan 16, no. 1 (2017): 17, https:// doi.org/10.36421/veritas.v16i1.8.

${ }^{10}$ Alvin Plantinga, God, Freedom and Evil (Grand Rapids: Eerdmans, 1977). 
Teodisi lain yang juga sering diajukan sebagai pembelaan adalah pandangan greater good yang menekankan pada providensi Allah. Jessica Layantara menjelaskan pandangan ini sebagai berikut, "Kejahatan datang oleh karena dosa manusia, namun tidak di luar kedaulatan Allah. Kejahatan yang terjadi juga ada di dalam kehendak Allah, bukan karena Allah menyetujui kejahatan, melainkan karena Allah memiliki tujuan yang lebih baik (greater good) di balik setiap peristiwa kejahatan."11 Kebaikan lebih besar yang dimaksudkan di sini adalah, di dalam providensi-Nya, Allah turut bekerja di dalam segala sesuatu yang terjadi, termasuk hal-hal buruk yang menimpa kehidupan manusia (dan Anak-Nya sendiri, Yesus Kristus) untuk menghasilkan kebaikan yang lebih tinggi, seperti membentuk jiwa dan karakter manusia, atau mengarahkan sejarah kehidupan manusia kepada tujuan tertinggi yang dikehendaki-Nya (bdk. Ef. 1:11; Kej. 50:20 dan khotbah-khotbah para rasul dalam Kis. 2-4). Dan semua tindakan Allah tersebut tidaklah meniadakan (atau kompatibel dengan) kehendak bebas dan tanggung jawab manusia. $^{12}$

Dua teodisi di atas mengindikasikan bahwa pengertian dunia yang "baik" menurut kita tidak sama dengan "baik" menurut Allah, dan memang tidak seharusnya demikian. Kita tidak bisa mendefinisikan sepatu yang baik dan mobil yang baik dengan kategori "baik" yang sama. Sepatu yang baik berarti sepatu yang nyaman dipakai ketika berjalan, sedangkan mobil yang baik adalah mobil

\footnotetext{
${ }^{11}$ Jessica Layantara, "Kritik terhadap Teologi Proses dan Pembelaan terhadap Pandangan "Greater Good" dalam Menanggapi Masalah Kejahatan," Veritas: Jurnal Teologi Dan Pelayanan 16 no. 2 (2017): 156, https://doi.org/ 10.36421/veritas.v16i2.16

${ }^{12} \mathrm{Hal}$ ini disebut kompatibilisme. Penjelasan lebih lanjut mengenai kompatibilisme dapat dilihat dalam Layantara, "Kritik terhadap Teologi Proses dan Pembelaan terhadap Pandangan "Greater Good" dalam Menanggapi Masalah Kejahatan,” 161-164. Lihat juga Carson, "Biblical-Theological Pillars Needed To Support Faithful Christian Reflection On Suffering And Evil," 64-73.
}

yang bisa berfungsi dengan baik sebagai alat transportasi. Pengertian "baik" di sini harus sesuai dengan kategori dan fungsi masingmasing benda ketika dibuat. Sebab itu, dunia yang baik tidak bisa didefinisikan menurut pengertian kita pada umumnya: dunia yang bebas dari kejahatan, penderitaan dan rasa sakit serta, sebaliknya, memberikan kehidupan yang nyaman. Dunia yang terbaik menurut Allah Sang Pencipta adalah dunia yang memungkinkan manusia memilih untuk mengasihi dan menaati-Nya secara bebas dengan kapasitas moralnya, dan untuk mencapai hal tersebut kejahatan dan penderitaan diizinkan Allah terjadi untuk membentuk karakter manusia sebagai gambar Allah yang menjalani hidupnya seturut dengan rancangan Allah.

Di dalam memahami dan menghadapi kejahatan serta penderitaan yang terjadi di dalam hidup kita, salah satu wawasan yang diberikan oleh D.A. Carson kepada umat percaya adalah melihat segala sesuatu yang terjadi di dunia ini dari sudut pandang eskatologis: langit dan bumi baru yang kita rindukan dan penghukuman kekal yang kita takuti. ${ }^{13}$ Perspektif kekekalan ini menolong kita untuk menempatkan dan menjalani hidup di dalam kerangka dan prioritas yang benar, termasuk ketika menghadapi kejahatan dan penderitaan. Dalam edisi ini, tulisan dari Alexander D. Limasaputra yang berjudul "Bukti Penghakiman Allah Yang Adil di da-lam 2 Tesalonika 1:3-10 Menurut Pendekatan Analisis Wacana" memperlihatkan bagaimana Allah yang adil itu, pada akhirnya akan bertindak untuk menegakkan keadilanNya secara penuh dengan menghukum para penindas umat Allah yang tidak mau menaati injil, serta memberikan kelegaan dan penghiburan kepada umat-Nya. ${ }^{14}$

\footnotetext{
${ }^{13}$ Ibid., 58-61.

${ }^{14}$ Alexander D. Limasaputra, "Bukti Penghakiman Allah Yang Adil di dalam 2 Tesalonika 1:3-10 Menurut Pendekatan Discourse Analysis," Veritas: Jurnal Teologi Dan Pelayanan 19 no. 1 (2020): 69-84, https://doi.org/10.36421/ veritas.v19i1.349.
} 
Teodisi-teodisi di atas telah memaparkan argumentasi yang kuat dan logis mengenai keadilan dan kebaikan Allah di tengah kejahatan moral (moral evil) yang terjadi dalam dunia ini. Lantas bagaimana dengan penderitaan yang terjadi dalam kehidupan manusia yang bukan disebabkan oleh kejahatan mo-ral melainkan oleh peristiwa-peristiwa alam (natural evil), seperti pandemi COVID19 yang sedang terjadi saat ini? Teodisi yang biasa diajukan untuk menjawab natural evil adalah seluruh alam semesta juga ikut mengalami dampak dari kejatuhan manusia ke dalam dosa. Paulus menjelaskan hal ini dengan menyebutkan bahwa seluruh keberadaan ciptaan lain selain manusia "telah ditaklukkan kepada kesia-siaan” (Rm. 8:20) dan mengalami "perbudakan kebinasaan" (8:21). Dua ayat ini menunjukkan kenyataan bahwa alam semesta tidak mencapai tujuannya yang semula diciptakan yaitu memuliakan Allah dan secara literal hal itu berarti alam semesta mengalami kerusakan, kekacauan, dan pembusukan. ${ }^{15}$ Kesia-siaan dan kebinasaan alam semesta ini dapat terjadi karena Allah telah menjatuhkan kutuk kepada alam semesta akibat kejatuhan manusia pertama ke dalam dosa (Kej. 3:17). Karena itu, Paulus menjelaskan bahwa di dalam masa the already but not yet ini, ${ }^{16}$

\footnotetext{
${ }^{15}$ Alexander D. Limasaputra, "Memandang Penderitaan Melalui Perspektif The Already and The Not Yet dari Rasul Paulus," Veritas: Jurnal Teologi Dan Pelayanan 17 no.1 (2018): 52-53, https://doi.org/10.36421/veritas. v17i1.305.

${ }^{16}$ Perspektif the already but not yet dari rasul Paulus memiliki pengertian bahwa orang percaya saat ini hidup di dua masa yang tumpang tindih, yaitu masa kini (the present age) dan masa yang akan datang (the age to come). Di masa kini kuasa dosa, kutuk alam semesta dan pemerintahan Iblis hadir dan berkuasa atas dunia (1Kor. 2:6, 8; 2Kor. 4:4; Ef. 2:2; 6:11-12; Flp. 2:15). Sedangkan masa yang akan datang adalah masa di mana pemerintahan Allah berkuasa secara penuh (1Kor. 6:9; Gal. 5:21; Ef. 5:5; 1Tes. 2:12; 2Tim. 4:1) dan berakhirnya kuasa dosa, kutuk alam semesta dan pemerintahan Iblis (Rm. 8:21; Gal. 1:4). Jadi di masa the already and the not yet, kuasa dosa, kutuk alam semesta dan pemerintahan Iblis telah dipatahkan namun kehadirannya masih ada, dan pemerintahan Allah sudah hadir namun belum mencapai kepenuhannya (Ef. 1:21-22; Kol. 1:13; 2:14). Lihat ibid., 44-45.
}

manusia dan alam semesta akan sama-sama mengeluh (Rm. 8:22-23). Kata "mengeluh" dalam ayat ini merupakan ungkapan rasa sakit dan penderitaan yang teramat sangat dan tidak dapat diucapkan melalui katakata. Namun di sisi lain, mengeluh di sini sekaligus juga sebuah wujud penantian dan pengharapan akan kegenapan keselamatan di masa yang akan datang ketika orangorang percaya menerima kemuliaan yang penuh sebagai anak-anak Allah $(8: 21,23)$. Dengan perspektif seperti ini maka kita dapat menghadapi penderitaan dengan keyakinan yang sama seperti yang Paulus katakan, "Sebab aku yakin, bahwa penderitaan zaman sekarang ini tidak dapat dibandingkan dengan kemuliaan yang akan dinyatakan kepada kita” (Rm. 8:18).

Berbicara mengenai natural evil yang terkait dengan pandemi COVID-19 saat ini, timbul pertanyaan apakah virus sudah ada sejak awal dunia diciptakan? Tampaknya demikian. Virus adalah bagian dari ciptaan Allah yang baik. Virus yang tidak dikategorikan sebagai organisme hidup ${ }^{17}$ ini diperkirakan memiliki jumlah $10^{31}$ di bumi ini, atau 10 juta kali lipat lebih banyak dibandingkan jumlah bintang di angkasa luar. ${ }^{18}$ Para ilmuwan pada saat ini sudah menemukan banyak manfaat dari virus. Misalnya saja bakteriofag, virus yang menyerang dan menghancurkan bakteri. Bakteriofag berperan penting di dalam mengendalikan pertumbuhan bakteri. Dengan cara demikian, bakteriofag telah memelihara kehidupan seluruh makhluk hidup dengan menjaga siklus nutrien dan

\footnotetext{
${ }^{17}$ Berdasarkan klasifikasi dari Komite Internasional Taksonomi Virus yang dapat dilihat dalam Marc H. V. Regenmortel et al., ed., Virus Taxonomy: Seventh Report of the International Committee on Taxonomy of Viruses (San Diego: Academic Press, 2000), 4.

${ }^{18} \mathrm{Hal}$ ini dikemukakan oleh Anjeanette Roberts, seorang peneliti di bidang biologi molekuler dalam "More Viruses than Stars? No Way!," Theorems and Theology, September 2016, diakses 1 Juni 2020, https:// reasons.org/explore/blogs/theorems-theology/theoremstheology/2016/09/22/more-viruses-than-stars-no-way!
} 
keseimbangan ekologi bumi ini. ${ }^{19}$ Bakteriofag juga terbukti melindungi mikrobioma (seperti bakteri yang baik) yang ada di dalam tubuh manusia ${ }^{20}$ dan digunakan dalam terapi untuk mengobati beberapa penyakit. ${ }^{21}$ Bahkan virus yang mematikan sekalipun seperti HIV dapat digunakan dalam terapi gen untuk mengobati penyakit tertentu. ${ }^{22}$

Namun demikian, sesudah kejatuhan manusia ke dalam dosa, terjadi satu mekanisme perubahan yang menyebabkan mikrob seperti bakteri menjadi buruk bagi manusia. Ada tiga kemungkinan perubahan yang terjadi, atau pun kombinasi dari ketiganya. ${ }^{23}$ Pertama, terjadi pemindahan mikrob yang pada mulanya dirancang untuk berfungsi baik di area terbatas, setelah kejatuhan menjadi tersebar ke berbagai area dan menyebabkan berbagai penyakit dan disrupsi. Kedua, mikrob mengalami modifikasi secara fisik sehingga menjadi bersifat patogen (menyebabkan penyakit). Ketiga, mikrob mengalami pertumbuhan yang sangat tidak terkendali sehingga menyebabkan disrupsi pada keseimbangan ekosistem dan berakibat pada munculnya penyakit. Hal ini pula yang terjadi pada virus Corona baru (SARS-CoV2). Virus ini semula berasal dari hewan dan

${ }^{19}$ Jerry Bergman, "Did God Make Pathogenic Viruses?," Journal of Creation 13, no 1 (April 1999): 115125.

${ }^{20}$ Joe Francis, Matthew Ingle, dan Todd Charles Woo, "Bacteriophages as beneficial regulators of the mammalian microbiome" dalam Proceedings of the Eighth International Conference on Creationism 8 (2018):152157, https://doi.org/10.15385/jpicc.2018.8.1.16.

${ }^{21}$ Xavier Wittebole, Sophie De Roock, dan Steven M. Opal, "A Historical Overview of Bacteriophage Therapy as an Alternative to Antibiotics for the Treatment of Bacterial Pathogens," Virulence 5 no. 1 (2014): 226235, https://doi.org/10.4161/viru.25991.

${ }^{22}$ Nathalie Cartier et al., "Hematopoietic Stem Cell Gene Therapy with a Lentiviral Vector in X-Linked Adrenoleukodystrophy," Science 326, no 5954 (2009): 818-823, https://doi.org/10.1126/science.1171242.

${ }^{23}$ Joe Francis, "Good Design Gone Bad," Answers in Genesis, Oktober 2011, diakses 1 Juni 2020, https:// answersingenesis.org/evidence-for-creation/design-innature/good-designs-gone-bad. kemudian berpindah ke manusia, atau yang sering disebut dengan istilah zoonosis. ${ }^{24}$

\section{BAGAIMANA RESPONS KRISTEN TERHADAP PENDERITAAN YANG SEDANG TERJADI?}

Dengan kesadaran bahwa Allah punya maksud dan tujuan yang baik ketika menciptakan dunia dengan mengizinkan adanya penderitaan serta Dia sendiri pun turut bekerja di dalam segala sesuatu untuk menggenapi tujuan akhir yang telah direncanakan-Nya, maka bagaimanakah respons dan sikap kita yang tidak seharusnya dan yang seharusnya terhadap penderitaan yang sedang terjadi di dunia saat ini?

Pertama, kita tidak bersikap fatalistis secara teologis dan praktis. ${ }^{25}$ Sikap fatalistis ini lahir dari pemahaman teologis yang terlalu menekankan kedaulatan Allah secara berlebihan sedemikian rupa sehingga meniadakan tanggung jawab manusia yang juga menjadi penyebab dari penderitaan tersebut. Pemahaman yang fatalistis ini menghasilkan respons yang pasrah dan pasif dalam menghadapi penderitaan. Teodisi yang sudah dipaparkan sebelumnya di atas memperlihatkan kompatibilisme antara kedaulatan Allah dan kehendak bebas manusia serta tindakanNya di dalam dunia yang tidak melanggar hukum alam dan hukum moral yang sudah ditetapkan-Nya. Dengan pemahaman teodisi seperti ini maka manusia juga memiliki andil dan tanggung jawab terhadap penderitaan yang diakibatkan oleh ulahnya sendiri ketika melanggar hukum alam dan hukum moral yang telah ditetapkan Allah.

Kedua, kita tidak bersikap menyangkal, atau bereaksi secara berlebihan terhadap pende-

${ }^{24}$ Joe Francis, "COVID-19, Coronavirus, and Creation Virology," Answers in Genesis, Maret 2020, diakses 1 Juni 2020, https://answersingenesis.org/coronavirus/ covid19-coronavirus-and-creation-virology.

${ }^{25}$ Gunawan, "Meneropong Makna Penderitaan Manusia Menurut Konsep Teodise C.S. Lewis,” 29. 
ritaan. Sikap yang seperti ini lahir dari pemahaman yang salah terhadap penderitaan, bahwa penderitaan bukanlah rancangan dan kehendak Allah bagi manusia sehingga harus disingkirkan dari kehidupan manusia. Teodisi greater good yang sudah dijabarkan sebelumnya memperlihatkan bahwa Allah mengizinkan penderitaan dialami oleh manusia untuk tujuan yang lebih tinggi, yaitu menggenapi rencana-Nya dan pembentukan karakter manusia. Karena itu, rasul Paulus sendiri memandang penderitaan sebagai sebuah kesempatan yang indah untuk mengalami persekutuan dengan Kristus (yang juga menderita dan mati di atas kayu salib) sedemikian rupa sehingga ia bisa mengalami kuasa kebangkitan-Nya dan makin mengenal Dia (Flp. 3:10). Rasul Petrus juga memandang penderitaan sebagai kesempatan untuk meneladani jejak Kristus yang sudah lebih dulu menderita demi keselamatan umat percaya supaya kita hidup untuk kebenaran (1Ptr. 2:21-24).

Ketiga, dengan menghindari sikap pertama yang pasif dan sikap kedua yang reaktif maka kita mesti bersikap proaktif. Umat percaya harus tetap memandang ke depan di dalam pengharapan akan kedatangan Kristus yang kedua kali untuk menggenapi keselamatan dan menegakkan keadilan-Nya secara sempurna. Di dalam penantian itu, kita sebagai umat Allah dipanggil untuk bersikap tabah menghadapi penderitaan dan proaktif bertindak dengan meneladani Yesus Kristus sendiri. Menyikapi perdebatan di antara para murid yang membicarakan penyebab penderitaan seorang yang buta sejak lahir, Yesus mengajak para murid untuk melihat bahwa penderitaan adalah sebuah kesempatan untuk ikut ambil bagian di dalam pekerjaanpekerjaan Allah yang harus dinyatakan dan Ia pun segera bertindak menolong orang buta itu (Yoh. 9:1-7). Dalam edisi ini, tulisan Herry Susanto yang berjudul "Panggilan Sosial Gereja Berdasarkan Pelayanan Yesus Dalam Lukas 4:18-19: Sebuah Upaya Merevitalisasi Pelayanan Gereja" mengajak kita sebagai umat Allah yang dipanggil ke tengah dunia ini, untuk meneladani Yesus dengan melakukan pelayanan sosial kepada masyarakat yang membutuhkan. ${ }^{26}$ Di dalam upaya mewujudkan sebuah pelayanan sosial yang berdampak nyata bagi masyarakat, Adrianus Yosia dalam tulisannya yang berjudul "Merupa Wujud Evangelikalisme di Indonesia: Suatu Usulan Awal" mengajak gereja-gereja dan lembaga-lembaga pelayanan Kristen di Indonesia untuk bersatu sebagai satu tubuh di dalam Kristus mengerjakan visi yang sama, yaitu menyatakan kuasa Injil Kristus yang sanggup mengubahkan kehidupan manusia. ${ }^{27}$

\section{KESIMPULAN}

Terjadinya pandemi COVID-19 di seluruh dunia pada saat ini memunculkan kembali pertanyaan klasik yang menjadi "tumit Achilles" iman Kristen: mengapa Allah yang mahakuasa dan mahabaik bisa menciptakan dunia yang di dalamnya terdapat kejahatan dan penderitaan? Mengapa Allah yang mahakuasa dan mahabaik itu tidak menyingkirkan kejahatan dan penderitaan dari dunia ini? Pertanyaan-pertanyaan yang telah meresahkan umat manusia di sepanjang sejarah ini telah melahirkan berbagai respons teologis yang disebut teodisi. Tulisan ini telah menjelaskan beberapa teodisi Kristen yang dibangun di atas dasar teologi yang biblikal seperti pembelaan kehendak bebas, providensi Allah untuk mencapai tujuan yang lebih tinggi (greater good), kompatibilisme antara kedaulatan Allah dan tanggung jawab manusia dalam mempraktikkan kehendak bebas, dan teologi Paulus tentang kejatuhan

\footnotetext{
${ }^{26}$ Herry Susanto, "Panggilan Sosial Gereja Berdasarkan Pelayanan Yesus Dalam Lukas 4:18-19: Sebuah Upaya Merevitalisasi Pelayanan Gereja," Veritas: Jurnal Teologi Dan Pelayanan 19 no. 1 (2020): 97-112, https://doi.org/ 10.36421/veritas.v19i1.356.

${ }^{27}$ Adrianus Yosia, "Merupa Wujud Evangelikalisme di Indonesia: Suatu Usulan Awal," Veritas: Jurnal Teologi Dan Pelayanan 19 no. 1 (2020): 85-95, https://doi.org/10.36421/ veritas.v19i1.339.
} 
manusia yang berdampak pada rusaknya seluruh tatanan dunia ciptaan serta dua masa yang saling tumpang tindih (the already but not yet). Teodisi-teodisi tersebut telah memperlihatkan pribadi Allah yang berdaulat, mahakuasa dan mahabaik, yang masih terus bekerja di dalam segala sesuatu yang terjadi di dunia ini baik secara langsung maupun melalui hukum alam dan hukum moral yang telah ditetapkan-Nya untuk merealisasikan tujuan akhir yang telah direncanakan-Nya. Teodisi-teodisi ini dapat menjadi fondasi iman yang logis dan kokoh bagi kita, umat percaya, untuk terus beriman kepada Allah yang mahakuasa dan mahabaik sekalipun di tengah kejahatan dan penderitaan yang terjadi dalam dunia ini. Selain respons teologis, kita juga dipanggil untuk bersatu secara proaktif mengerjakan pelayanan kasih kepada sesama yang membutuhkan sebagai bentuk kemuridan yang menaati Tuhan Yesus Kristus yang telah lebih dulu mendemonstrasikan kasih Allah kepada du-nia ini.

\section{DAFTAR KEPUSTAKAAN}

Alinurdin, David. "Allah versus Setan Laplace: Sebuah Usulan Konsep Tindakan Ilahi Khusus yang Trinitarian, Kovenantal dan Saintifik." Veritas: Jurnal Teologi dan Pelayanan 19, no. 1 (2020): 25-49. https://doi.org/10.36421/veritas.v19i1.340.

Bergman, Jerry. "Did God Make Pathogenic Viruses?" Journal of Creation 13, no 1 (April 1999): 115-125.

Carson, D.A. "Biblical-Theological Pillars Needed To Support Faithful Christian Reflection On Suffering And Evil." Trinity Journal 38NS (2017): 55-77.

Cartier, Nathalie, Salima Hacein-Bey-Abina, Cynthia C. Bartholomae, Gabor Veres, Manfred Schmidt, et al. "Hematopoietic Stem Cell Gene Therapy with a Lentiviral Vector in X-Linked Adrenoleukodystrophy." Science 326, no 5954 (2009): 818-823. https://doi.org/10.1126/ science.1171242.

Craig, William L. Five Arguments for God: The
New Atheism and the Case for the Existence of God. London: Christian Evidence Society, 2016.

Francis, Joe, Matthew Ingle, dan Todd Charles Woo. "Bacteriophages as beneficial regulators of the mammalian microbiome." Dalam Proceedings of the Eighth International Conference on Creationism 8 (2018):152-157. https://doi.org/ 10.15385/jpicc.2018.8.1.16.

Francis, Joe. "Good Design Gone Bad." Answers in Genesis, Oktober 2011. Diakses 1 Juni 2020. https://answersingenesis.org/ evidence-for-creation/design-in-nature/ good-designs-gone-bad.

-. "COVID-19, Coronavirus, and Creation Virology." Answers in Genesis, Maret 2020. Diakses 1 Juni 2020. https:// answersingenesis.org/coronavirus/ covid19-coronavirus-and-creationvirology.

Gunawan, Esther. "Meneropong Makna Penderitaan Manusia Menurut Konsep Teodise C.S. Lewis." Veritas: Jurnal Teologi dan Pelayanan 16, no. 1 (2017): 17. https:// doi.org/10.36421/veritas.v16i1.8.

Layantara, Jessica. "Kritik terhadap Teologi Proses dan Pembelaan terhadap Pandangan 'Greater Good' dalam Menanggapi Masalah Kejahatan.” Veritas: Jurnal Teologi Dan Pelayanan 16 no. 2 (2017): 155-168. https://doi.org/10.36421/veritas. v16i2.16.

Lewis, C.S. The Problem of Pain. 1940. Reprint, New York: HarperCollins, 2009. Adobe PDF ebook.

Limasaputra, Alexander D. "Bukti Penghakiman Allah Yang Adil di dalam 2 Tesalonika 1:3-10 Menurut Pendekatan Analisis Wacana." Veritas: Jurnal Teologi Dan Pelayanan 19 no. 1 (2020): 69-84. https://doi.org/10.36421/veritas.v19i1.349.

Limasaputra, Alexander D. "Memandang Penderitaan Melalui Perspektif The Already and The Not Yet dari Rasul Paulus." Veritas: Jurnal Teologi Dan Pelayanan 17 no.1 (2018): 43-60. https://doi. org/10.36421/veritas.v17i1.305. 
Mackie, J.L. "Evil and Omnipotence." Mind 64 no. 254 (April 1955): 200-212. https:// doi.org/10.1093/mind/LXIV.254.200.

Maleachi, Martus A. dan Hendra Yohanes. "Kehadiran Tuhan Di Tengah UmatNya: Dari Penciptaan Ke Penciptaan Yang Baru." Veritas: Jurnal Teologi dan Pelayanan 19, no. 1 (2020): 11-24. https:// doi.org/10.36421/veritas.v19i1.361.

Plantinga, Alvin. God, Freedom and Evil. Grand Rapids: Eerdmans, 1977.

Regenmortel, Marc H.V., Claude M. Fauquet, Dave H.L. Bishop, E.B. Carsten, M.K. Estes, S.M. Lemon, J. Maniloff, M.A. Mayo, D.J. McGeoch, C.R. Pringle, R.B. Wickner, ed. Virus Taxonomy: Seventh Report of the International Committee on Taxonomy of Viruses. San Diego: Academic Press, 2000.

Roberts, Anjeanette. "More Viruses than Stars? No Way!" Theorems and Theology, September 2016. Diakses 1 Juni 2020. https://reasons.org/explore/blogs/ theorem s-theology/theorem stheology/2016/09/22/more-viruses-thanstars-no-way!
Susanto, Herry. "Panggilan Sosial Gereja Berdasarkan Pelayanan Yesus Dalam Lukas 4:18-19: Sebuah Upaya Merevitalisasi Pelayanan Gereja." Veritas: Jurnal Teologi Dan Pelayanan 19 no. 1 (2020): 97-112. https://doi.org/10.36421/veritas.v19i1.356.

Wittebole, Xavier, Sophie De Roock dan Steven M Opal. "A Historical Overview of Bacteriophage Therapy as an Alternative to Antibiotics for the Treatment of Bacterial Pathogens." Virulence 5 no. 1 (2014): 226-235. https://doi.org/10.4161/viru.25991.

Yosia, Adrianus. "Merupa Wujud Evangelikalisme di Indonesia: Suatu Usulan Awal" Veritas: Jurnal Teologi Dan Pelayanan 19 no. 1 (2020): 85-95. https:// doi.org/10.36421/veritas.v19i1.339.

Yuliana, Fitri. "Menjawab Tuduhan Inkoherensi dari John Hick terhadap Konsep Dwinatur dalam Doktrin Inkarnasi Ortodoks." Veritas: Jurnal Teologi dan Pelayanan 19, no. 1 (2020): 51-68. https:// doi.org/10.36421/veritas.v19i1.344. 